FORGETTING CHILDREN BORN OF WAR 



\section{FORGETTING CHILDREN BORN OF WAR}

Setting the Human Rights Agenda in Bosnia and Beyond 
COLUMBIA UNIVERSITY PRESS

PUBLISHERS SINCE 1893

NEW YORK CHICHESTER, WEST SUSSEX

Copyright (C) 2010 Columbia University Press

All rights reserved

Library of Congress Cataloging-in-Publication Data

Carpenter, R. Charli.

Forgetting children born of war : setting the human rights agenda in Bosnia and beyond /

R. Charli Carpenter.

p. $\mathrm{cm}$.

Includes bibliographical references and index.

ISBN 978-0-231-15130-6 (alk. paper) — ISBN 978-0-231-52230-4 (ebook)

1. Children and war-Bosnia and Hercegovina. 2. Children's rights-Bosnia and Hercegovina.

I. Title.

HQ784.W3C38 2010

$362.87-\mathrm{dc2} 2$

2010006615

(2)

Columbia University Press books are printed on permanent and durable acid-free paper.

This book is printed on paper with recycled content.

Printed in the United States of America

c 10987654321

References to Internet Web sites (URLs) were accurate at the time of writing. Neither the author nor Columbia University Press is responsible for URLs that may have expired or changed since the manuscript was prepared. 
To all my children 

I am a war baby. -Ryan Badol, Bengali-Canadian.

Who will save the war child, baby? Who controls the key? The web we weave is thick and sordid, fine by me. War child, victim of political pride. Plant the seed, territorial greed. Mind the war child, we should mind the war child. _ "War Child," The Cranberries 
